\title{
원조예측성 및 원조분업에 관한 실무회의
}

원조예측성 및 원조 분업에 관한 실무회의가 2010년 6월 29일 OECD에서 개최되었음. 동 회의에서는 OECD/DAC사무국에서 발간 예정인 2010년도 원조예측성 보고서(2010 DAC Report on Aid Predictability) 초안 및 2010년도 원조분업보고서(2010 OECD Report on Division of Labor)의 구성 등에 관한 논의 가 진행되었으며, 주요 사항은 아래와 같음.

\section{I. 회의 개요}

그최 일시 : 2010년 6월 29일

○ 주제

(1) 2010년도 원조예측성 보고서 (2010 DAC Report on Aid Predictability)

(2) 2010년도 원조 분업 보고서 (2010 OECD Report on Division of Labor)

\section{II. 요지}

\section{2010년도 원조예측성 보고서 초안 검토}

1) 동 보고서의 전망

Country Programmable Aid(이하 CPA) 비율의 증가세가 둔화되고 있어 향후 원조 예측성 및 천 년개발목표(MDGs)달성에도 부정적 영향을 미칠 것

2) 미국과 영국을 포함한 다수 회원국의 제시 의견

(1) 동 보고서의 효용성 제고를 위해서, 공여국의 $\mathrm{CPA}$ 집행계획보다는 각 수원국별로 유입되는 $\mathrm{CPA}$ 규모와 추이에 초점을 맞추는 것이 적절함.

(2) $\mathrm{CPA}$ 의 범주, 산출방식, 전략적 확대 가능성에 대해서는 추가적 논의가 필요함. 
3) DAC사무국의 원조예측성 달성률 산정방식 제시 내용 및 동 사무국의 요청사항

(1) 원조예측성달성률(Predictability Ratio) $=\frac{\text { Disbursed CPA }}{\text { Reported CPA }}$

(단, 동 산정방식의 타당성에 대하여 추가적인 논의를 실시하기로 함)

(2) 동 보고서의 작성목적이 세계적인 차원의 원조예측성의 추이를 파악하는 데 있으므로, 회원국 들의 적극적인 참여와 협조가 필요

\section{2010년도 원조분업 보고서 작성방향}

1) 동 보고서 작성의 목적

원조의 중복과 분절현상을 개선하여 원조소외국(aid orphans)에 대한 지원을 증가시키고자 함.

\section{2) 포르투갈 등 다수 회원국의 의견}

지역적 원조배분(global aid allocation)측면은 물론, 수원국내에서의 분야별·지역별 공여국간 분 업에도 관심을 가지는 것이 필요함.

\section{3) 한국의 의견}

(1) 원조소외국은 주로 수원의지가 미약하고 부패·열악한 치안문제로 인해 사업추진환경이 열악한 국가들이며, 최근 경제위기가 이른바 '모범수원국'에 대한 지원의 집중을 심화시킴.

(2) 따라서 보고서의 목적은 'global aid resources의 효율적 활용'이 되어야 하며, 각 수원국 내 지역·분야에 대한 공여국간 분업·조화 내용을 강화해 줄 것을 제안

4) 사무국의 계획

금년 말 서울에서 개최되는 ‘원조체계에 관한 워크숍’에서 동 보고서의 핵심내용을 소개할 예정임. 